\title{
Anal human papillomavirus infection in HIV-positive men and women at two opportunistic infections clinics in Harare, Zimbabwe
}

\author{
Simbarashe Chinyowa ${ }^{1 *}$ (D), Joel M. Palefsky ${ }^{2}, Z_{\text {Zvavahera M. Chirenje }}^{3}$, Rudo Makunike-Mutasa ${ }^{4}$, \\ Marshall Munjoma ${ }^{3}$ and Godfrey I. Muguti ${ }^{1}$
}

\begin{abstract}
Background: HIV-infected individuals are at increased risk of anal cancer; in the majority of cases this is linked to human papillomavirus (HPV) infection. Anal cancer screening is not routinely offered in Zimbabwe.

Methods: A cross-sectional study was performed on 152 patients (88 females; 64 males) attending Opportunistic Infection Clinics at 2 tertiary hospitals between November 2014 and June 2015. Demographic data, immunological parameters and behavioural characteristics were collected. An anal swab was collected from each patient for HPV genotype testing. HPV testing was performed using MY09/MY11 PCR, followed by typing using the dot blot method.

Results: The mean age was 39.6 years (range, 18-69 years). Median CD4 count was 375 cells/ $\mu \mathrm{L} .96 \%$ were on antiretroviral therapy. Only one patient identified as a man who has sex with men. Of 122 samples tested for HPV, 54 were positive (44\%). HPV was three times more common in females (60\%) than males (20\%). Being HPV-positive was associated with history of perianal warts, history of cervical intraepithelial neoplasia and having more than ten lifetime sexual partners. The most commonly detected high-risk HPV genotypes were HPV-58 (13\%), HPV-31 (11\%) and HPV-16 (9\%). Nine patients harboured multiple high-risk HPV types. The two most commonly detected low-risk genotypes were HPV-11 (17\%) and HPV-53 (11\%).
\end{abstract}

Conclusion: Overall anal HPV prevalence was 44\% in this mostly heterosexual HIV-positive population. Oncogenic HPV types accounted for almost half of infections, supporting the need for surveillance of anal cancer in this population.

Keywords: Anal, Human papillomavirus, HIV, Men, Women, Africa

\section{Introduction}

Anal cancer is rare in the general population but is significantly more prevalent in high-risk groups such as men who have sex with men (MSM) and those infected with human immunodeficiency virus (HIV). In up to $90 \%$ of cases anal cancer is linked to human papillomavirus (HPV) infection [1]. HIV predisposes an individual to multiple and often persistent anal HPV infections. There has been a downward trend in HIV prevalence in Zimbabwe thanks to aggressive efforts to manage the

\footnotetext{
* Correspondence: drchinyowa@gmail.com

${ }^{1}$ Department of Surgery, University of Zimbabwe College of Health Sciences, P.O. Box A178 Avondale, Harare, Zimbabwe

Full list of author information is available at the end of the article
}

epidemic. However, the overall burden of HIV in the general population is still high, at $13 \%$ [2].

A substantial amount of data are now available from studies on anal HPV infections and consequent disease in MSM. There are numerous HPV genotypes and anal cancer in this population is most strongly linked to persistent HPV-16 and HPV-18 infection [3]. However data from other high-risk groups, in particular, African heterosexual males and females are relatively scant [4].The patterns of HPV infection, HPV clearance or progression to anal squamous intraepithelial lesions and cancer in this latter group are yet to be fully elucidated.

Anecdotal observation and crude cancer registry data suggest an upward trend in the number of cases of anal

(c) The Author(s). 2018 Open Access This article is distributed under the terms of the Creative Commons Attribution 4.0 International License (http://creativecommons.org/licenses/by/4.0/), which permits unrestricted use, distribution, and reproduction in any medium, provided you give appropriate credit to the original author(s) and the source, provide a link to the Creative Commons license, and indicate if changes were made. The Creative Commons Public Domain Dedication waiver (http://creativecommons.org/publicdomain/zero/1.0/) applies to the data made available in this article, unless otherwise stated. 
cancer in Zimbabwe in the past few years. Anal cancer screening is not routinely offered in Zimbabwe. Against this backdrop we sought to establish the prevalence of anal HPV infection in asymptomatic HIV-positive patients presenting at two Opportunistic Infections Clinics (OIC) in two large urban hospitals in Harare.

\section{Methods}

A cross-sectional study was performed on 152 consecutive patients (88 females; 64 males) attending OIC at Parirenyatwa Group of Hospitals and Harare Central Hospital between November 2014 and June 2015. Eleven patients opted not to be included in this study with the main reason given for refusal being lack of time. A total of 9000 adult patients are enrolled at the two OIC, with a male:female ratio of 1:1.5. The OIC serve a low to middle-income urban population of Harare, Zimbabwe. Patients visit the OIC for HIV testing and counselling services, routine follow up of HIV disease, and fulfilment of prescribed antiretroviral drugs. $85 \%$ of patients enrolled at the OIC are on highly active antiretroviral therapy (HAART). Ethical approval for this study was obtained from the University of Zimbabwe, College of Health Sciences Joint Research Ethics Committee and the Harare Central Hospital Ethics Committee. The study was registered with the Medical Research Council of Zimbabwe.

Males and females age $\geq 18$ years were included in the study after providing informed signed consent. The source test document was checked to verify that each participant was HIV-positive. Demographic data and behavioural characteristics were collected through a face-to-face structured interview. CD4 counts and viral loads were verified by inspection of the participant's clinical record.

\section{Anal sample collection}

The participant was positioned on a standard examination couch in the left lateral position with knees drawn up to the chest and buttocks at the edge of the bed. The perianal region was inspectedafter gently parting the buttocks. A Dacron-tipped swab was moistened in $0.9 \%$ normal saline, then introduced blindly into the anal canal as far as possible [5]. Using the external anal sphincter as a fulcrum, the swab was firmly rotated against the anal canal wall for $30 \mathrm{~s}$ while being withdrawn from the anal canal. Clean scissors were used to cut off the Dacron tip of the swab into a labelled $2 \mathrm{ml}$ cryotube containing $0.5 \mathrm{ml} 10 \%$ guanidine thiocyanate and frozen at $-70{ }^{\circ} \mathrm{C}$ until analysis.

\section{HPV genotyping}

HPV testing was done using primer pair MY09/MY11 polymerase chain reaction (PCR), followed by typing using the dot blot method, as described previously [5]. For internal quality control beta-globin was co-amplified during each PCR run and was probed for using a human beta-globin gene probe. Samples that tested negative for beta-globin were excluded from analysis.

Samples were thawed to room temperature. HPV DNA was extracted using the conventional ammonium acetate method. AmpliTaq Gold Polymerase enzyme was added to the samples to amplify target DNA. The PCR cycles were at: $95^{\circ} \mathrm{C}$ for 9 min, 40 cycles of $\left(95^{\circ} \mathrm{C}\right.$ for $1 \mathrm{~min}, 55{ }^{\circ} \mathrm{C}$ for $1 \mathrm{~min}$ and $72{ }^{\circ} \mathrm{C}$ for $1 \mathrm{~min}$ ), $72{ }^{\circ} \mathrm{C}$ for 5 min and then held at $4{ }^{\circ} \mathrm{C}$. After PCR, the DNA amplification mixture was denatured using an alkaline buffer then, applied to a Biodyne B membrane. The DNA was fixed to the Biodyne $\mathrm{B}$ membrane by baking at $80{ }^{\circ} \mathrm{C}$ for $1 \mathrm{~h}$ and then exposed to an HPV L1 consensus probe mixture. A sample was defined as HPV-positive if it reacted positively to the consensus probe mixture. Hybridisation was then carried out between the sample DNA and specific biotin-labelled HPV probes for 14 high-risk HPV genotypes $(16,18,31,33,35,39,45,51$, $52,56,58,59,66$ and 68 ) and 15 low-risk HPV genotypes $(6,11,26,32,40,53,54,55,61,69,70,73,82,83$ and 84 ). The hybridization products were then detected using enhanced chemiluminescence (ECL). Commercial HPV standards were blotted onto each membrane as positive controls for their respective genotype.

\section{Statistical analysis}

Data collection forms were inspected for completeness and accuracy by trained study personnel. Patients with missing data for a particular analysis were excluded only from that analysis. Data was analysed using IBM SPSS Statistics for Windows, version 22 (IBM Corp., Armonk, N.Y., USA). Comparison between groups of frequencies was performed with Chi-square test or Fisher's exact test of association. All results were evaluated at a 95\% confidence interval; significance was set at $p<0.05$.

\section{Results}

Data from 122 patients were analysed after excluding 30 whose samples tested negative for beta-globulin; 73 (60\%) were female and $49(40 \%)$ were male. The mean age was 39.6 years (Range 18-69; SD 10.7). All patients were Black Africans. A summary of the study population is shown in Table 1.

Whilst we set out to probe for 14 high-risk and 15 low-risk HPV genotypes, we chose not to report results for genotypes 26, 70 and 82 (intermediate risk) and genotypes 32, 54, 55 and 61 (low-risk) due to lack of availability of working standards for those particular genotypes. These genotypes were therefore excluded from analyses and are not reported. Fifty-four of 122 samples tested HPV positive (44\%). Of the 54 HPV-positive 
Table 1 Characteristics of the study population $(N=122)$

\begin{tabular}{lll}
\hline Characteristic & & \\
\hline Age (years) & Mean (SD) & $39.6(10.7)$ \\
Sex & & $\mathrm{n}(\%)$ \\
& Male & $49(40.2)$ \\
& Female & $73(59.8)$ \\
Marital status & & \\
& Single & $21(17.2)$ \\
& Married & $67(54.9)$ \\
& Divorced & $13(10.7)$ \\
& Widowed & $21(17.2)$
\end{tabular}

\section{Current CD4}

Median (IQR)

$375(235-557)$

CD4 nadir

$$
\text { Median (IQR) }
$$

$141(65-597)$

Time since HIV diagnosis

$$
\begin{aligned}
& <1 \text { year } \\
& 1 \text { to } 5 \text { years } \\
& >5 \text { years }
\end{aligned}
$$

Age at first sex

$$
\text { Median (IQR) }
$$

$19(18-21)$

Number of lifetime sexual partners

$$
\begin{aligned}
& <5 \\
& 5 \text { to } 10 \\
& >10
\end{aligned}
$$

Sexual orientation

$$
\text { Heterosexual }
$$

Receptive anal intercourse

$$
\text { Ever }
$$$$
\text { Never }
$$

Condom use

$\begin{array}{ll}\text { Regular } & 71(58.2) \\ \text { Occasional } & 44(36.0) \\ \text { Never } & 7(5.8)\end{array}$

History of anal warts

$\begin{array}{ll}\text { Yes } & 18(14.8) \\ \text { No } & 104(85.2)\end{array}$

History of CIN/cervical cancer (women only)

$\begin{array}{ll}\text { Yes } & 3(4.1) \\ \text { No } & 70(95.9)\end{array}$

History of VIN/vulvar cancer (women only)

$\begin{array}{ll}\text { Yes } & 0(0.0) \\ \text { No } & 73(100.0)\end{array}$

samples, 49 (91\%) had specific HPV genotypes detected. Anal HPV was detected in 10/49 males (20\%) and in 44/ 73 females (60\%). High risk HPV types were detected in 25 patients (20\%); low-risk HPV types were detected in 24 patients (20\%). Nine patients (7\%) had multiple high-risk HPV types i.e. more than one specific high-risk HPV type detected per sample. All high-risk HPV genotypes that we sought except HPV-39 were detected in this study population.

Table 2 summarises the prevalence and type distribution of HPV genotypes in the study sample.

The most commonly detected high-risk HPV genotypes were HPV-58 (13\%), HPV-31 (11\%) and HPV-16 (9\%). HPV-18 was detected in $2.5 \%$ of samples. HPV-11 (17\%) and HPV-53 (11\%) were the two most commonly detected low-risk genotypes.

Figures 1 and 2 show the type-specific distribution of anal HPV infections in the study sample.

A positive test for any HPV was significantly associated with female gender $(p<0.0001)$. It was not significantly associated with marital status, HAART (highly active anti-retroviral therapy) use, cigarette smoking, alcohol use, number of sex partners, condom use, current CD4 count nor nadir CD4 count. For males and females combined, detection of any high-risk HPV was significantly associated with $\geq 5$ lifetime partners $(p=0.021)$. When data were analysed for males and females separately, there was no change noted in the above associations. A summary of statistical associations between a positive HPV result and selected socio-demographic and immunological factors is shown in Table 3.

\section{Discussion}

In this study of a largely heterosexual, HIV-positive population in Harare, Zimbabwe, the overall prevalence

\begin{tabular}{|c|c|c|c|c|c|c|}
\hline & \multicolumn{2}{|c|}{$\begin{array}{l}\text { Males } \\
(n=49)\end{array}$} & \multicolumn{2}{|c|}{$\begin{array}{l}\text { Females } \\
(n=73)\end{array}$} & \multicolumn{2}{|c|}{$\begin{array}{l}\text { All } \\
(n=122)\end{array}$} \\
\hline & $\mathrm{N}$ & $(\%)$ & $n$ & $(\%)$ & $n$ & $(\%)$ \\
\hline Any HPV type & 10 & 20.4 & 44 & 60.3 & 54 & 44.3 \\
\hline Any low risk HPV type & 5 & 10.2 & 19 & 26.0 & 24 & 19.7 \\
\hline Any high risk HPV type & 5 & 10.2 & 20 & 27.4 & 25 & 20.5 \\
\hline Multiple high risk HPV types ${ }^{a}$ & 1 & 2.0 & 8 & 11.0 & 9 & 7.4 \\
\hline
\end{tabular}
of anal HPV infection (high-risk and low-risk HPV genotypes) was $44 \%$. This is the first paper describing prevalence of anal HPV infection in African heterosexual men, and one of the first in African women.

The anal HPV prevalence in females was three-fold higher than in men (60\% vs. 20\%). Most studies on females note that prevalence of anal HPV is actually higher than cervical HPV [6]. Putatively the cervix acts as a reservoir

Table 2 Summary HPV prevalence by genotype 


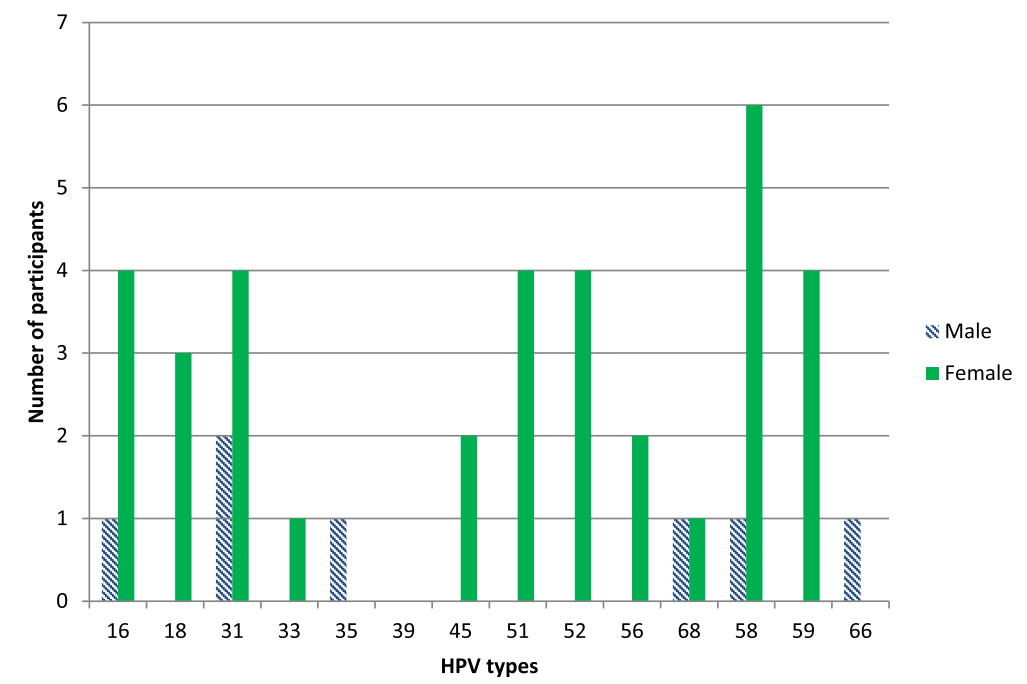

Fig. 1 Distribution of high-risk HPV genotypes among patients who tested HPV positive

for HPV infections, allowing cross-infections with other sites such as the anus [7]. Simpson et al. suggest that in women, post-toilet front-to back wiping is a plausible biological mechanism for introduction of HPV into the anal canal [8]. There is likely under-reporting of anal sex in our study as this is a cultural taboo. Nonetheless, it is notable that the prevalence in males, though less than in females, is substantial, and suggests the importance of screening for anal cancer in both male and female HIV-positive patients regardless of self-reported sexual practices $[9,10]$.

High-risk HPV prevalence was $21 \%$ being found in $10 \%$ of males and $27 \%$ of females. Overall HPV- 16 was found at a prevalence of $4 \%$ which is important because HPV-16 is one of the most consistent genotypes associated with anal cancer [11]. To date, however, studies on prevalence of HPV-16 in anal cancer samples have included no or very few samples, from Africa. In a recent meta-analysis by Lin et al. that included 2358 anal cancer samples, only 23 samples were from studies in Africa [12]. As more data become available it will become clearer how significant a role HPV-16 plays in anal cancer within the African population. An interesting finding in our data is that HPV-58 was the most common high-risk type detected. Other local and regional studies have also noted HPV-58 to be amongst the most frequently detected in the genital region $[13,14]$. This may reflect different geographical distribution of HPV genotypes than reported elsewhere in the world. In

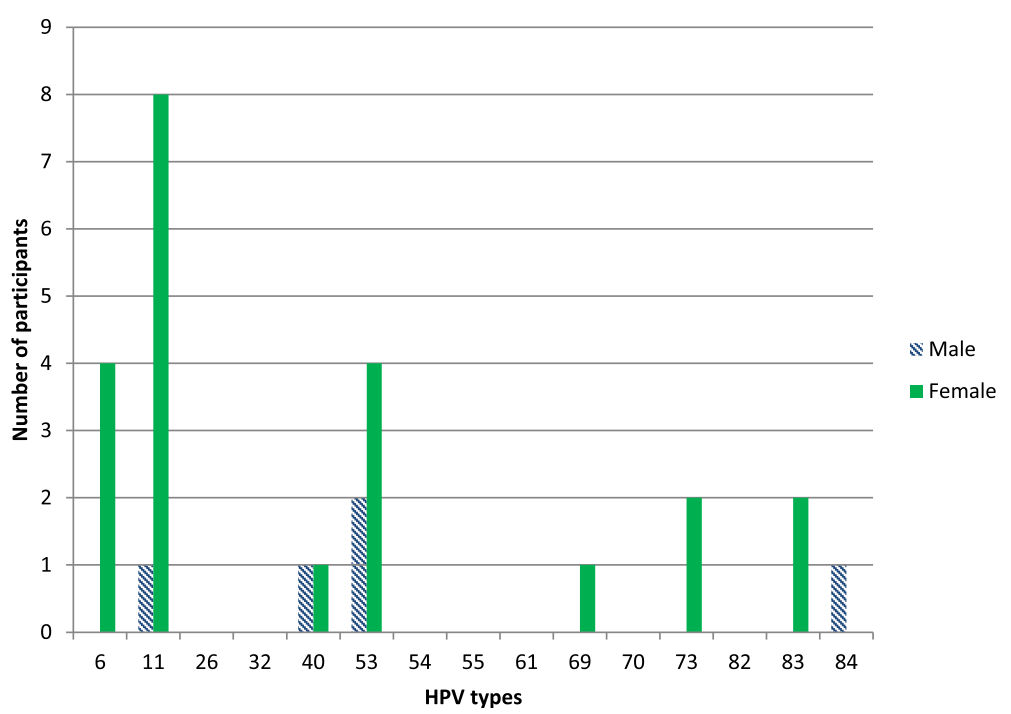

Fig. 2 Distribution of low-risk HPV genotypes among patients who tested HPV positive. *Data for HPV-26, 32, 54, 55, 61, 70 and 82 are not reported (see text for detail) 
Table 3 Relationship between positive HPV result and select demographic, immunological and behavioural variables

\begin{tabular}{|c|c|c|c|c|c|c|}
\hline & \multicolumn{3}{|c|}{$\begin{array}{l}\text { Any HPV positive } \\
(N=54)\end{array}$} & \multicolumn{3}{|c|}{$\begin{array}{l}\text { Any high-risk HPV positive } \\
(N=25)\end{array}$} \\
\hline & $\mathrm{n}$ & $\%$ & $p$-value & $\mathrm{N}$ & $\%$ & $p$-value \\
\hline \multicolumn{7}{|l|}{ Sex } \\
\hline Male & 10 & 20.4 & 0.000 & 5 & 11.6 & 0.294 \\
\hline Female & 44 & 60.3 & & 20 & 18.7 & \\
\hline \multicolumn{7}{|l|}{ Marital Status } \\
\hline Single & 8 & 44.4 & 0.552 & 3 & 15.0 & 0.634 \\
\hline Married & 27 & 32.1 & & 12 & 14.1 & \\
\hline Widowed & 13 & 44.8 & & 7 & 24.1 & \\
\hline Divorced & 6 & 40.0 & & 3 & 20.0 & \\
\hline \multicolumn{7}{|l|}{ Education } \\
\hline Primary school & 4 & 26.7 & 0.569 & 3 & 20.0 & 0.900 \\
\hline Secondary school & 37 & 40.2 & & 15 & 16.1 & \\
\hline Tertiary education & 13 & 41.9 & & 6 & 18.8 & \\
\hline \multicolumn{7}{|l|}{ Employment } \\
\hline Formal employment & 8 & 38.1 & 0.545 & 5 & 22.7 & 0.551 \\
\hline Informal employment & 31 & 41.9 & & 13 & 16.9 & \\
\hline Unemployed & 15 & 31.9 & & 6 & 12.5 & \\
\hline \multicolumn{7}{|l|}{ Currently on HAART } \\
\hline No & 2 & 33.3 & 0.809 & 0 & 0.0 & 0.256 \\
\hline Yes & 52 & 38.2 & & 25 & 17.7 & \\
\hline \multicolumn{7}{|l|}{ Time since HIV diagnosis } \\
\hline$<1 \mathrm{yr}$ & 11 & 50.0 & 0.454 & 4 & 17.4 & 0.999 \\
\hline 1 to $5 \mathrm{yr}$ & 24 & 38.7 & & 11 & 17.7 & \\
\hline$>5 \mathrm{yr}$ & 19 & 34.5 & & 10 & 17.5 & \\
\hline \multicolumn{7}{|l|}{ Smoking } \\
\hline Current & 1 & 33.3 & 0.991 & 0 & 0.0 & 0.643 \\
\hline Past & 7 & 36.8 & & 3 & 15.0 & \\
\hline Never & 46 & 37.1 & & 22 & 17.3 & \\
\hline \multicolumn{7}{|l|}{ Alcohol intake } \\
\hline Current & 4 & 57.1 & 0.534 & 1 & 12.5 & 0.751 \\
\hline Past & 18 & 36.7 & & 7 & 14.0 & \\
\hline Never & 32 & 36.0 & & 17 & 18.5 & \\
\hline \multicolumn{7}{|c|}{ Number of lifetime sex partners } \\
\hline$<5$ & 37 & 36.6 & 0.414 & 16 & 15.8 & 0.021 \\
\hline 5 to 10 & 12 & 50.0 & & 8 & 34.8 & \\
\hline$>10$ & 5 & 41.7 & & 0 & 0.0 & \\
\hline \multicolumn{7}{|l|}{ Condom use } \\
\hline Regular & 31 & 34.8 & 0.730 & 12 & 12.9 & 0.060 \\
\hline Occasional & 7 & 36.8 & & 3 & 15.8 & \\
\hline Never & 6 & 46.2 & & 5 & 38.5 & \\
\hline \multicolumn{7}{|l|}{ Sexual orientation } \\
\hline Heterosexual & 54 & 38.8 & & 25 & 17.6 & \\
\hline Homosexual & 0 & 0.0 & & 0 & 0.0 & \\
\hline
\end{tabular}

addition, or alternatively, the frequent detection of HPV-58 may be a reflection of the relatively slow rate at which this particular genotype is cleared. Shvetsov et al. found that HPV-59 and 58 had the longest clearance times in a Hawaiian study of healthy women [15].

Overall, low-risk HPV infections were as common as high-risk infections in our study ( $20 \%$ vs. $21 \%)$. Though low-grade types are much less oncogenic by definition, they cause a significant burden of genital warts. The majority of these warts are attributable to infection by HPV-6 and 11 [16]. These are bothersome to the patient and difficult to treat [17]. This is an important consideration as Zimbabwe, through the Ministry of Health and Child Care, is in the process of rolling out a nationwide vaccination programme. The currently available vaccine is divalent, providing protection against HPV-16 and HPV-18 [18]. Ideally a vaccine protecting against HPV-6 and HPV-11 would reduce the future burden of genital warts.

There are several limitations to our results. The study was cross-sectional yet many HPV infections are transient [15]. We used the MY09/MY11 primer set for PCR and the dot blot method for HPV typing. These are older methods compared to newer technologies such as next-generation DNA sequencing. They are not able to detect all possible HPV types in the anogenital region but enabled us to describe the prevalence of the most important HPV types known to be associated with cervical and anal cancer and their precursor lesions. In addition we chose not to report on the prevalence of 7 other lower risk HPV genotypes (26, 32, 54, 55, 61, 70 and 82). Our overall HPV positivity remains unaffected because consensus primers were used initially, as do our results for the specific genotypes most commonly associated with anogenital cancer in Africa. Self-reporting of sexual practices may be unreliable especially where such practices are stigmatising. There is likely under-reporting of anal sexual intercourse in our study, especially by men, for this reason. Our study was set in two urban hospital clinics. This limits the generalisation of our findings to the rest of Zimbabwe where behavioural risk for sexually transmitted infections and access to health care may be different.

\section{Conclusions}

In conclusion the prevalence of anal HPV was $44 \%$ in this group of largely heterosexual HIV-positive males and females. Oncogenic HPV genotypes accounted for almost half of infections, supporting the need for surveillance of anal cancer in this population. These data represent a baseline upon which future studies may be built. Specifically, longitudinal studies can potentially reveal the pattern of persistence of anal HPV and chronicle the development of cytopathological changes over time. 


\section{Abbreviations}

DNA: Deoxyribonucleic acid; HAART: Highly active antiretroviral therapy; HIV: Human immunodeficiency virus; HPV: Human papillomavirus; MSM: Men who have sex with men; OIC: Opportunistic Infections Clinic;

PCR: Polymerase chain reaction

\section{Acknowledgements}

We are grateful to all the clinical and laboratory staff involved in this work.

\section{Funding}

This research was partly funded by a Novel Educational Clinical Trainees and Research (NECTAR) scholarship (Grant number R24TW008905). Funders of the study had no role in the study design, data collection, data analysis, data interpretation and writing up of the report.

\section{Availability of data and materials}

The datasets used and/or analysed during the current study are available from the corresponding author on reasonable request.

\section{Authors' contributions}

This work was carried out by all authors in collaboration. Study concept and design: SC, GM, RM, ZMC and JP. Clinical data collection: SC. MM oversaw the laboratory work. Drafting of the initial manuscript: SC. All authors: critical revision of the manuscript. All authors read and approved the final manuscript.

\section{Ethics approval and consent to participate}

Ethical clearance for the study was granted by Parirenyatwa Hospital and College of Health Sciences Joint Research Ethics Committee (ref. JREC/183/ 14) and the Harare Central Hospital Ethics Committee (ref. 020514/24). The research was registered with the Medical Research Council of Zimbabwe (ref. B/684). All participants provided signed written consent prior to participation.

\section{Consent for publication}

Not applicable.

\section{Competing interests}

The authors declare that they have no competing interests.

\section{Publisher's Note}

Springer Nature remains neutral with regard to jurisdictional claims in published maps and institutional affiliations.

\section{Author details}

'Department of Surgery, University of Zimbabwe College of Health Sciences, P.O. Box A178 Avondale, Harare, Zimbabwe. ${ }^{2}$ Department of Medicine, University of California, San Francisco, USA. ${ }^{3}$ Department of Gynaecology, University of Zimbabwe College of Health Sciences, Harare, Zimbabwe. ${ }^{4}$ Department of Histopathology, University of Zimbabwe College of Health Sciences, Harare, Zimbabwe.

\section{Received: 22 February 2018 Accepted: 31 October 2018}

\section{Published online: 14 November 2018}

\section{References}

1. Zandberg DP, Bhargava R, Badin S, Cullen KJ. The role of human papillomavirus in nongenital cancers. CA Cancer J Clin. 2013;63:57-81. https://doi.org/10.3322/caac.21167.

2. Joint United Nations Program on HIV/AIDS (UNAIDS), Ministry of Health and Child Welfare (Zimbabwe), National AIDS Council (Zimbabwe). Zimbabwe Global AIDS Response Progress Report 2012.

3. Salati SA, Al Kadi A. Anal cancer - a review. Int J Health Sci (Qassim). 2012;6: 206-30

4. Stanley M, Winder D, Sterling J, Goon P. HPV infection, anal intra-epithelial neoplasia (AIN) and anal cancer: current issues. BMC Cancer. 2012;12:398 https://doi.org/10.1186/1471-2407-12-398.

5. Palefsky JM, Holly EA, Ralston ML, Jay N. Prevalence and risk factors for human papillomavirus infection of the anal canal in human immunodeficiency virus (HIV)-positive and HIV-negative homosexual men. J Infect Dis. 1998;177:361-7.
6. Stier EA, Sebring MC, Mendez AE, Ba FS, Trimble DD, Chiao EY. Prevalence of anal human papillomavirus infection and anal HPV-related disorders in women : a systematic review. Am J Obstet Gynecol. 2015. https://doi.org/10. 1016/.jajog.2015.03.034.

7. Moscickia A-B, Schiffmanb M, Burchellc A, Alberod G, Giulianoe A, Goodmanf MT, et al. Updating the natural history of human papillomavirus and Anogenital cancers. Vaccine. 2013;30. https://doi.org/10.1016/j.vaccine. 2012.05.089.Updating.

8. Simpson S, Blomfield P, Cornall A, Tabrizi SN, Blizzard L, Turner R. Front-toback \& dabbing wiping behaviour post-toilet associated with anal neoplasia \& HR-HPV carriage in women with previous HPV-mediated gynaecological neoplasia. Cancer Epidemiol. 2016;42:124-32. https://doi.org/10.1016/j.canep. 2016.04.001.

9. AC-P N. Anal cancer and human papillomaviruses in heterosexual men. Curr Oncol. 2008:15:204-5.

10. Piketty C, Darragh TM, Da Costa M, Bruneval P, Heard I, Kazatchkine MD, et al. High prevalence of anal human papillomavirus infection and anal cancer precursors among HIV-infected persons in the absence of anal intercourse. Ann Intern Med. 2003;138:453-9.

11. Machalek DA, Poynten M, Jin F, Fairley CK, Farnsworth A, Garland SM, et al Anal human papillomavirus infection and associated neoplastic lesions in men who have sex with men: a systematic review and meta-analysis. Lancet Oncol. 2012;13:487-500. https://doi.org/10.1016/S14702045(12)70080-3.

12. Lin C, Franceschi S, Clifford GM. Human papillomavirus types from infection to cancer in the anus, according to sex and HIV status: a systematic review and meta-analysis. Lancet Infect Dis. 2017;18:198-206. https://doi.org/10. 1016/S1473-3099(17)30653-9.

13. Smith-McCune KK, Shiboski S, Chirenje MZ, Magure T, Tuveson J, Ma Y, et al. Type-specific cervico-vaginal human papillomavirus infection increases risk of HIV acquisition independent of other sexually transmitted infections. PLOS One. 2010;5:e10094. https://doi.org/10.1371/journal.pone.0010094.

14. McDonald AC, Tergas Al, Kuhn L, Denny L, Wright TC. Distribution of human papillomavirus genotypes among HIV-positive and HIV-negative women in Cape Town, South Africa. Front Oncol. 2014;4:48. https://doi.org/10.3389/ fonc.2014.00048.

15. Shvetsov YB, Hernandez BY, McDuffie K, Wilkens LR, Zhu X, Ning L, et al. Duration and clearance of anal human papillomavirus (HPV) infection among women: the Hawaii HPV cohort study. Clin Infect Dis. 2009:48:536-46.

16. Hariri S, Unger ER, Sternberg M, Dunne EF, Swan D, Patel S, et al. Prevalence of genital human papillomavirus among females in the United States, the National Health and Nutrition Examination Survey, 2003-2006. J Infect Dis. 2011;204:566-73. https://doi.org/10.1093/infdis/jir341.

17. Thurgar E, Barton S, Karner C, Edwards SJ. Clinical effectiveness and costeffectiveness of interventions for the treatment of anogenital warts: systematic review and economic evaluation. Health Technol Assess (Rockv). 2016;20:1-485. https://doi.org/10.3310/hta20240.

18. Chin'ombe N, Sebata NL, Ruhanya V, Matarira HT. Human papillomavirus genotypes in cervical cancer and vaccination challenges in Zimbabwe. Infect Agent Cancer. 2014:9:16. https://doi.org/10.1186/1750-9378-9-16.
- fast, convenient online submission

- thorough peer review by experienced researchers in your field

- rapid publication on acceptance

- support for research data, including large and complex data types

- gold Open Access which fosters wider collaboration and increased citations

- maximum visibility for your research: over $100 \mathrm{M}$ website views per year

At $\mathrm{BMC}$, research is always in progress.

Learn more biomedcentral.com/submissions 